\title{
KETAHANAN USANG BARANG JADI KARET PEGANGAN SETANG SEPEDA MOTOR DARI TEPUNG KULIT KERANG
}

\author{
Ageing Resistance of Motorcycle Rubbery Grip Handle from Flour Clamshell
}

\author{
Rahmaniar \\ Balai Riset dan Standardisasi Industri Palembang \\ Pos-el : rahmaniar_een@yahoo.co.id \\ (Artikel diterima 6 Januari; direvisi $1 \overline{6}$ Maret 2016; disetujui 20 Mei 2016)
}

\begin{abstract}
Padding used to strengthen and enlarge rubber volume, can improve the quality of rubbery goods' physical characteristics and vulcanization. The objectives of the research were to obtain the formulation of rubber compound met SNI standardvaried with particle size of flour clamshell and ratio composition of padding (clamshell flour: carbon black). The experimental design of the research was Completely Randomized Factorial Design. The first factor was concentration of clamshell flour in particle size (A): A1:30 phr, A2: $40 \mathrm{phr}$, A3: 50 phr. The second was ratio composition of padding (clamshell flour: carbon black N330) (B): $B 1=15: 55 \mathrm{phr}, B 2=25: 45 \mathrm{phr}$ and B3=35:35 phr. Testing on quality of rubber compound's characteristics includevisual test, modulus, and ageing resistance including hardness, tensile strength, elongation at break. The result showed that visual test for physical compound characteristics value is no defect for all formula, 55 - 104\% for modulus, while compound physical test after ageing process shows 56 - 64 shore $A$ for hardness, $106-129 \mathrm{~kg} / \mathrm{cm} 2$ for tensile strength, $336-579 \%$ for elongation at break. Test result for all parameters meets SNI 06-7031-2004 as the standard for motorcycle grip handle.
\end{abstract}

Keywords: rubber compound, Flour Clamshell, carbon black.

\begin{abstract}
Abstrak Bahan pengisi berfungsi sebagai penguat yang dapat memperbesar volume karet, dapat memperbaiki sifat fisis barang jadi karet dan memperkuat vulkanisat. Penelitian ini bertujuan untuk mendapatkan formulasi kompon karet yang memenuhi SNI, dengan variasi ukuran partikel tepung kulit kerang dan variasi perbandingan bahan pengisi (tepung kulit kerang:carbon black). Rancangan yang digunakan adalah Rancangan Acak Lengkap (RAL), Faktor pertama konsentrasi tepung kulit kerang dengan ukuran partikel $(A): A_{1}: 30 \mathrm{phr}, A_{2}: 40 \mathrm{phr}, A_{3} ; 50 \mathrm{phr}$. Faktor kedua variasi bahan pengisi (Tepung kulit kerang:carbon black N330) (B) $: B_{1}=15: 55$ phr, $B_{2}=25: 45$ phr dan $B_{3}=35: 35$ phr.Pengujian mutu karakteristik kompon karet yaitu uji visual, tegangan tarikdan ketahanan usang meliputi kekerasan, tegangan putus, perpanjangan putus. Hasil penelitian menunjukkan bahwa nilai karakteristik fisik kompon hasil uji visual untuk seluruh formula yaitu tidak cacat,tegangan tarik (modulus) 55-104\%, sedangkan hasil uji fisik kompon setelah pengusangan yaitu kekerasan (hardness) 56-64 shore A, tegangan putus (tensile strength) $106-129 \mathrm{~kg} / \mathrm{cm}^{2}$, perpanjangan putus (elongation at break) $336-579 \%$. Hasil uji yang dilakukan untuk semua parameter memenuhi SNI 06-7031-2004 persyaratan mutu karet pegangan setang (grip handle) sepeda motor.
\end{abstract}

Kata kunci: kompon karet, tepung kulit kerang, carbon black.

\section{PENDAHULUAN}

Karet terdiri dari karet alam dan karet sintetis, karet alam tersusun dari hidrokarbon karet dan senyawa non-karet. Salah satu senyawa non-karet adalah protein. Senyawa non-karet lain adalah karbohidrat, lipid, karoten, glikolipid, mineral, enzim, fosfolipid dan berbagai bahan lain. Karet alam berasal dari tumbuhan Hevea brasiliensis yang merupakan polimer alam dengan monomer isoprena. Polimer karet alam terdiri dari $97 \%$ polimer cis-1,4-polyisoprene (Yuniari, 2001; Ellul, 1994).

Karet alam merupakan salah satu komoditas perkebunanyang memiliki peranan penting dalam perekonomian nasional, yakni sebagai sumber devisa negara dan sumber penghidupan jutaan petani (Haris, 2004). Luas area dan produksi perkebunan rakyat di Provinsi Sumatera Selatan 1.221.413 
ha dan 1.071.853 ton (Dinas Perkebunan Provinsi Sumatera Selatan, 2013).

Barang jadi karet diproses dari kompon karet yang divulkanisasi. Proses vulkanisasi merupakan pembentukan ikatan silang kimia dari rantai molekul yang berdiri sendiri, yang dapat meningkatkan elastisitas dan menurunkan plastisitas (Kumar dan Nijasure, 2007). Agar dihasilkan barang jadi karet yang layak digunakan terlebih dulu karet mentah dicampur dengan bahan kimia lain misalnya bahan pengisi, bahan pelunak, bahan penggiat, anti oksidan, bahan pencepat, bahan pewarna dan bahan kimia lainnya.

Kompon karet campuran antara karet mentah dengan bahan-bahan kimia lainnya, yang ditentukan komposisi dan pencampurannya dilakukan dengan cara penggilingan, komposisi kompon karet berbeda-beda tergantung pada tujuan pembuatan barang jadi karetnya.

Untuk meningkatkan nilai ekonomis dari cangkang, menurut Yuniati, (2010). Filler cangkang kerang kipas dapat menurunkan swelling index dan menaikkan sifat mekanis kompon. Cangkang kerang dapat digunakan sebagai filler karena mengandung kalsium karbonat 89,91\% (Darma, 1988). Disamping itu limbah padat dari cangkang kerang dimanfaatkan sebagai bahan kerajinan sebagai desain interior, kosmetik, memanfaatkan kandungan nutrisi, beton, makanan ternak dan pembuatan lem kaca (Nadjib, 2008; Rezeki A.S dan Karolina R, 2013; Agustini et al, 2011).

Bahan Pengisi ditambahkan ke dalam kompon karet dalam jumlah yang cukup besardengan tujuan untuk meningkatkan sifat fisik, memperbaiki karakteristik pengolahan tertentudan mengurangi biaya produksi. Bahan pengisi dibagi atas dua yaitu bahan pengisi aktif dan bahan pengisi tidak aktif. Limbah dari kulit kerang ini memberikan peluang usaha bila di olah dan dimanfaatkan, sehingga akan meningkatkan kualitas dari limbah yang dapat meningkatkan nilai ekonomi dari limbah tersebut serta menjadikan limbah tersebut ramah lingkungan. Permukaan dalam lapisan luar dari kulit kerang menghasilkan periostracium organik merupakan lapisan cangkang plecypoda yang berupa lapisan kapur pada cangkang banyak mengandung kalsium karbonat kira-kira 89,91\%. (Darma, 1988).

Lapisan terdalam terdiri dari
lamella yang sangat tipis mengandung kalsiumkarbonat dalam bentuk calcitic, aragonite atau keduanya yang tertanam dalam matrik organik yang tipis. Kerang andara mengandung daging sekitar 30\% dari berat keseluruhan yang mengandung mineral-mineral kalsium, fosfat, besi, yodium dan tembaga, kerang ini menghasilkan limbah padat yang cukup tinggi, sedangkan kulit kerang merupakan salah satu batuan calcareous yang mengandung kadar $\mathrm{CaO}$ yang tinggi ( Surest et al, 2012), sehingga perlu adanya upaya untuk menanganinya agar bermanfaat dan mengurangi dampak negatif terhadap lingkungan. Bahan pengisi dari limbah kulit kerang yang mengandung kalsium karbonat diharapkan dapat meningkatkan sifat fisika baik dari produk barang jadi karet, maka akan dilakukan penelitian penggunaan kulit kerang yang mengandung kalsium karbonat sebagai bahan pengisi yang diharapkan dapat meningkatkan sifat-sifat mekanik produk jadi karet yang dihasilkan.

Pemanfaatan tepung kulit kerang dapat dijadikan sebagai bahan tambahan pada industri, yang digunakan sebagai bahan dalam pembuatan kompon karet. Adapun tujuan dari penelitian ini untuk mendapatkan formulasi kompon karet yang memenuhi $\mathrm{SNI}$, dengan variasi ukuran partikel tepung kulit kerang dan variasi perbandingan bahan pengisi (tepung kulit kerang:carbon black).

\section{BAHAN DAN METODE Bahan}

Bahan-bahan yang digunakan dalam penelitian ini adalah SIR 20, SBR, zink oksida, asam stearat, sulfur, Kulit kerang, Carbon black N330, Monarex oil, cumaron resin, CBS, TMTD, TMQ,

\section{Peralatan}

Peralatan yang digunakan dalam penelitian ini adalah open mill $L 140 \mathrm{~cm}$ $D 18 \mathrm{~cm}$ kapasitas $1 \mathrm{~kg}$, , pressing rubber, moulding, cutting scrub, neraca analitis, 
timbangn metler p120 kapasitas $1200 \mathrm{~g}$, glassware, timbangan duduk merek Berkel kapasitas $15 \mathrm{~kg}$, cutting scraf besar, alat press, cetakan sheet, autoclave, furnace, glassware dan gunting.

\section{Rancangan Percobaan}

Rancangan penelitian yang digunakan Faktor pertama tepung kulit kerang dengan ukuran partikel $(A): A_{1}: 30$ mesh, $A_{2}: 40$ mesh dan $A_{3}: 50$ mesh. Dari ketiga ukuran partikel tersebut untuk masing-masing variasi mesh diambil jumlah (phr) kulit kerang (faktor kedua).

Faktor kedua variasi jumlah bahan pengisi yaitu tepung kulit kerang dan Carbon Black N330(B) :

$$
\begin{aligned}
& \mathrm{B}_{1}: 15 \text { phr: } 55 \mathrm{phr} \\
& \mathrm{B}_{2}: 25 \mathrm{phr}: 45 \mathrm{phr} \\
& \mathrm{B}_{3}: 35 \mathrm{phr}: 35 \mathrm{phr} .
\end{aligned}
$$

Dalam penelitian ini formula pembuatan kompon karet dengan menggunakan pengisi tepung kulit kerang dan carbon blackterdapat

\begin{tabular}{|c|c|c|c|c|c|c|c|c|c|c|}
\hline NO & NAMA BAHAN & \multicolumn{9}{|c|}{ FORMULA } \\
\hline 1. & RSS & \multicolumn{3}{|c|}{75} & \multicolumn{3}{|c|}{75} & \multicolumn{3}{|c|}{75} \\
\hline 2. & EPDM & \multicolumn{3}{|c|}{25} & \multicolumn{3}{|c|}{25} & \multicolumn{3}{|c|}{25} \\
\hline 3. & Kulit kerang & \multicolumn{3}{|c|}{$\begin{array}{c}30 \text { mesh } \\
\text { phr }\end{array}$} & \multicolumn{3}{|c|}{$\begin{array}{c}40 \text { mesh } \\
\text { phr }\end{array}$} & \multicolumn{3}{|c|}{$\begin{array}{c}50 \text { mesh } \\
\text { phr }\end{array}$} \\
\hline \multirow{3}{*}{4.} & & 15 & 25 & 35 & 15 & 25 & 35 & 15 & 25 & 35 \\
\hline & Carbon Black & & phr & & & phr & & & phr & \\
\hline & N330 & 55 & 45 & 35 & 55 & 45 & 35 & 55 & 45 & 35 \\
\hline 5. & Minarex oil & 5 & 5 & 5 & 5 & 5 & 5 & 5 & 5 & 5 \\
\hline 6. & Cumaron resin & 3 & 3 & 3 & 3 & 3 & 3 & 3 & 3 & 3 \\
\hline 7. & $\mathrm{ZnO}$ & 5 & 5 & 5 & 5 & 5 & 5 & 5 & 5 & 5 \\
\hline 8. & SA & 2 & 2 & 2 & 2 & 2 & 2 & 2 & 2 & 2 \\
\hline 9. & BHT & 1,5 & 1,5 & 1,5 & 1,5 & 1,5 & 1,5 & 1,5 & 1,5 & 1,5 \\
\hline 10. & CBS & 0,7 & 0,7 & 0,7 & 0,7 & 0,7 & 0,7 & 0,7 & 0,7 & 0,7 \\
\hline 11. & MBTS & 0,5 & 0,5 & 0,5 & 0,5 & 0,5 & 0,5 & 0,5 & 0,5 & 0,5 \\
\hline 12. & Sulfur & 2 & 2 & 2 & 2 & 2 & 2 & 2 & 2 & 2 \\
\hline
\end{tabular}
pada Tabel 1.

Tabel 1. Formula Kompon Karet

Sumber : Kania, et al, 2014.

\section{Tahapan Penelitian}

\section{Pembuatan Filler dari Kulit Kerang}

1) Pisahkan antara kulit dengan isi

2) Pembersihan dari kotoran-kotoran yang melekat langsung dibakar sampai menjadi abu atau bisa juga dimasukkan kedalam oven dengan suhu $121^{\circ} \mathrm{C}$ selama 15 menit.

3) Setelah itu kulit kerang dihancurkan di dalam crusher.

4) Kulit kerang yang sudah hancur kemudian dipisahkan atau diayak dengan menggunakan sieve

5) Tepung kulit kerang yang lolos dari sieve dimasukkan dalam ball mill selama 3 jam untuk mendapatkan tepung kulit kerang yang lebih halus dan yang tidak lolos sieve dimasukkan dalam crusher lagi untuk mendapatkan hasil yang lebih halus

6) Setelah 3 jam, tepung kulit kerang kemudian dipisahkan atau diayak menggunakan sieve untuk mendapatakan tepung kulit kerang sesuai ukuran (30 mesh,40 mesh dan 50 mesh)

\section{Pembuatan kompon karet (Thomas, 2005)}

1. Persiapan bahan

Bahan kimia dari masing-masing formula kompon ditimbang sesuai dengan 
yang telah ditentukan. Jumlah dari setiap bahan didalam formula kompon dinyatakan dalam PHR (berat per seratus karet) dengan memperhatikan faktor konversinya.

\section{Mixing ( pencampuran )}

Proses pencampuran dilakukan dalam gilingan terbuka (open mill), yang telah dibersihkan. Selanjutnya dilakukan proses:

a. Mastikasi polymer selama \pm 15 menit ( $70^{\circ}$ untuk kompon RSS dan EPDM).

b. Pencampuran polymer dengan bahan kimia:

1) Ditambahkan bahan penggiat/ activator ( $\mathrm{ZnO}$ dan asam stearat ) dan antioksidan(cumaron resin dan $\mathrm{BH}$ ). Potong setiap sisi satu sampai tiga kali selama \pm 10 menit.

2) Ditambahkan filler (tepung kulit kerang dan CB N330) dan softener (minarex oil). dipotong setiap sisi satu sampai tiga kali selama \pm 10 menit.

3) Ditambahkan accelerator(CBS dan MBTS),dipotong setiap sisi satu sampai tiga kali selama \pm 10 menit.

4) Kompon dikeluarkan dari open mill dan ditentukan ukuran ketebalan lembaran kompon dengan menyetel jarak roll pada cetakan sheet, dikeluarkan dan diletakkan diatas plastik transparan. Kompon dilakukan master bed \pm 24 jam.

5) Ditambahkanvulkanisator(sulfur). dipotong setiap sisi satu sampai tiga kali selama \pm 10 menit.

6) Dilakukan prosedur ini untuk kompon 1 sampai dengan kompon 3.

Kompon karet yang dihasilkan akan diuji mutunya sehingga dapat diketahui kelemahan maupun kelebihannya. Parameter yang diuji yaitu uji visual, ketahanan usang parameter Kekerasan (Hardness), Tegangan putus (Tensile strength), perpanjangan putus (Elongation at break) dan uji modulus (\%).

\section{HASIL DAN PEMBAHASAN}

\section{Uji Visual}

Kompon karet akan dilakukan pengujian secara visual terhadap adanya cacat atau kerusakan.

Hasil pengujian secara visual dilakukan terhadap kompon karet pegangan setang (grip handle) sepeda motor yang dihasilkan dari 9 formula dapat dilihat pada Tabel 2.

\section{Tabel 2. Hasil uji visual kompon karet} pegangan setang (grip handle).

\begin{tabular}{cccc}
\hline No & $\begin{array}{c}\text { Ukuran } \\
\text { partikel } \\
\text { (Mesh) }\end{array}$ & $\begin{array}{c}\text { Tepung kulit } \\
\text { kerang: } \\
\text { Carbon Black }\end{array}$ & Hasil uji \\
\hline 1. & 30 & $15: 55$ & \\
& & $25: 45$ & Tidak cacat \\
& & $35: 35$ & \\
2. & 40 & $15: 55$ & \\
& & $25: 45$ & Tidak cacat \\
& & $35: 35$ & \\
3. & 50 & $15: 55$ & \\
& & $25: 45$ & Tidak cacat \\
& & $35: 35$ & \\
\hline
\end{tabular}

Perlakuan dalam penelitian ini untuk variasi ukuran partikel 30, 40 dan 50 mesh terhadap campuran bahan pengisi tepung kulit kerang dan carbon black jika dilihat secara visual tidak berpengaruh secara signifikan, hal ini dapat dilihat hasil pengujian dari formula 1 sampai formula 9 terhadap kompon karet yang dihasilkan tidak cacat. Hasil pengamatan yang dilakukan terhadap kompon karet yang dihasilkan permukaan kompon karet rata, tidak terdapat bercak, tidak retak, tidak ada goresan, tidak berlubang, tidak sobek dan tidak ada benda asing lainnya.

Berdasarkan persyaratan SNI hasil uji kompon karet memenuhi persyaratan mutu karet pegangan setang (grip handle) sepeda motor SNI 06-7031-2004.Nilai cacat dapat disebabkan karena pencampuran yang tidakmerata, perbandingan penggunaan bahan baku dan bahan penolong yang tidak sesuai. Selain itu penggunaan temperatur pada saat pencampuran bahan tidak tepat, sehingga vulkanisasi tidak terjadi 
secara maksimal. Disamping itu pada saat pelepasan produk karet pegangan setang (grip handle) dari cetakan (moulding) dapat menyebabkan cacat produk.

\section{Ketahanan Usang, $70^{\circ} \mathrm{C}, 24$ jam (Ageing Resistance)}

Pengusangan mengakibatkan turunnya sifat fisik barang karet, seperti karet menjadi keras, lunak dan lengket. Penurunan sifat fisik disebabkan terjadinya degradasi karet karena oksidasi oleh oksigen dan ozon. Oksidasi dipercepat dengan adanya panas, sinar ultra violet, lembab dan logam yang mengkatalisa oksidasi. Uji ketahanan usang bertujuan untuk mengetahui kemunduran sifat-sifat fisik kompon karet seperti kekerasan, tegangan putus dan perpanjangan putus setelah pengusangan dalam waktu tertentu.

\section{Kekerasan (Shore A)}

Berdasarkan hasil pengujian kekerasan kompon karet setelah pengusangan dengan nilai tertinggi pada perlakuan $A_{1} B_{2}, A_{1} B_{3}$ dan $A_{2} B_{3}$ yaitu 64 shore $A$, dan terendah pada perlakuan $A_{3} B_{1}$ yaitu 56 shore $A$. Hasil pengujian kekerasansetelah pengusangan dapat dilihat pada Gambar 1.

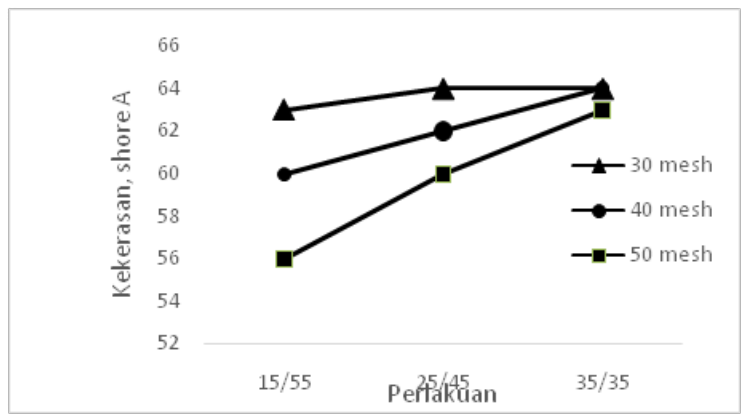

Gambar 1. Hasil uji kekerasan sebagai bahan pembuatan kompon karet dengan menggunakan tepung kulit kerang setelah pengusangan

Semakin besar tepung kulit kerang yang ditambahkan dibanding carbon black, nilai kekerasan cendrung meningkat, sedangkan ukuran partikel tepung kulit kerang tidak berpengaruh secara signifikan. Menurut Hendrawan dan Purboputro (2015), bahan pengisi dapat meningkatkan sifat fisis karet dalam pembuatan kompon karet. Nilai pengusangan dalam penelitian ini untuk semua perlakuan memenuhi SNI06-70312004 persyaratan mutu karet pegangan setang (grip handle) sepeda motor yaitu nilai awal \pm 10 (70 \pm 5$)$. Pengusangan mengakibatkan adanya perubahan nilai sebelum dan sesudah pengusangan. Variasi ukuran partikel tepung kulit kerang tidak berpengaruh secara signifikan terhadap nilai kekerasan setelah pengusangan hal ini dikarenakan ukuran partikel mempunyai rentang yang dekat sekali yaitu 30, 40 dan 50 mesh. Sedangkan perbandingan bahan pengisi antara tepung kulit kerang dan carbon black, cenderung semakin meningkat kan nilai kekerasan setelah pengusangan dengan penambahan tepung kulit kerang, bahan pengisi dalam pembuatan barang jadi karet merupakan matrial yang besar digunakan setelah campuran karet, bahan pengisi berfungsi untuk memperkuat karet, hal ini merupakan hal yang penting dalam teknologi pemprosesan karena dapat meningkatkan satu atau lebih sifat elastomer, sesuai kegunaannya.. Bahan pengisi akan meningkatkan banyaknya rantai polimer (Long, 1985).

\section{Tegangan putus}

Berdasarkan hasil pengujian tegangan putus kompon karet setelah pengusangan dengan nilai tertinggi pada perlakuan $A_{1} B_{3}$ yaitu $129 \mathrm{~kg} / \mathrm{cm}^{2}$ dan terendah pada perlakuan $\mathrm{A}_{3} \mathrm{~B}_{3}$ yaitu $106 \mathrm{~kg} / \mathrm{cm}^{2}$. Hasil pengujian tegangan putus kompon karet setelah pengusangan dapat dilihat pada Gambar 2.

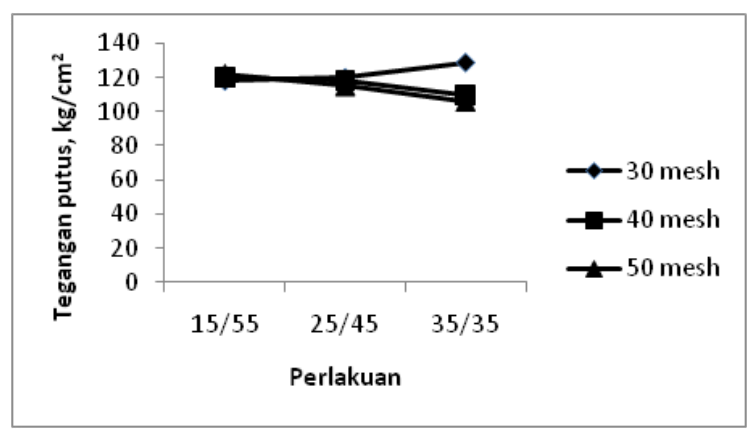

Gambar 2. Hasil uji tegangan putus sebagai bahan pembuatan kompon karet dengan menggunakan tepung kulit kerang setelah pengusangan 
Pengusangan mengakibatkan turunnya sifat fisik mekanik seperti tegangan putus selama masa penggunaan seperti karet menjadi retak, lunak dan lekat lekat. Penurunan sifat fisik ini disebabkan terjadinya degradasi karet karena oksidasi oleh oksigen dan ozon. (Chandra dan Rustgi, 1997). Nilai tegangan putus setelah pengusangan dalam penelitian ini untuk semua perlakuan memenuhi SNI 06-7031-2004 persyaratan mutu karet pegangan setang (grip handle) sepeda motor yaitu minimal 5. Semakin besar campuran kulit kerang nilai tegangan putus cenderung menurun, sedangkan ukuran partikel tidak berpengaruh secara signifikan hal ini dikarenakan kulit kerang merupakan bahan pengisi bukan penguat hanya berfungsi menambah volume saja. Menurut Maryam (2006) komposisi serbuk kulit kerang mengandung unsur $\mathrm{CaO}$ sekitar 66,7\%, $\mathrm{SiO}_{2} 7,88 \%, \mathrm{Fe}_{2} \mathrm{O}_{3}, 0,03 \%$, $\mathrm{MgO} 22,28 \%$ dan $\mathrm{Al}_{2} \mathrm{O}_{3} 1,25 \%$. Kalsium oksida $(\mathrm{CaO})$ merupakan senyawa turunan dari senyawa kalsium karbonat $\left(\mathrm{CaCO}_{3}\right)$, komposisi terbesar dari senyawa serbuk cangkang kerang mengandung 98,7\% $\mathrm{CaCO}_{3}$ (Retno,2012; Sahara, 2011).

\section{Perpanjangan putus}

Berdasarkan hasil pengujian perpanjangan putus kompon karet setelah pengusangan dengan nilai tertinggi pada perlakuan $A_{3} B_{1}$ yaitu $579 \%$ dan terendah pada perlakuan $A_{1} B_{1}$ yaitu $327 \%$. Hasil pengujian perpanjangan putus kompon karet setelah pengusangan dapat dilihat pada Gambar 3.

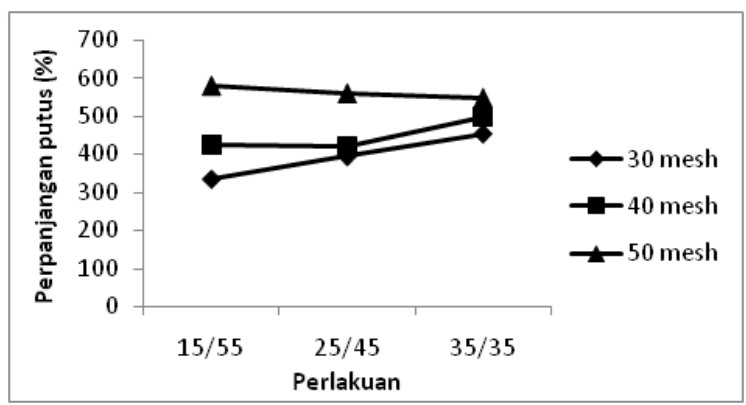

Gambar 3. Hasil uji perpanjangan putus sebagai bahan pembuatan kompon karet dengan menggunakan tepung kulit kerang setelah pengusangan
Nilai perpanjangan putus setelah pengusangan dalam penelitian ini untuk semua perlakuan memenuhi SNI 06-70312004 persyaratan mutu karet pegangan setang (grip handle) sepeda motor yaitu minimal 130. Semakin kecil ukuran partikel campuran tepung kulit karang yang di gunakan nilai perpanjangan putus cenderung meningkat tetapi tidak signifikan.

\section{Tegangan Tarik (Modulus \%)}

Berdasarkan hasil pengujian tegangan tarik kompon karet setelah pengusangan dengan nilai tertinggi pada perlakuan $A_{1} B_{1}$ yaitu $104 \%$ dan terendah pada perlakuan $A_{3} B_{1}$ yaitu55\%. Hasil pengujian tegangan tarik kompon karet setelah pengusangan dapat dilihat pada Gambar 4.

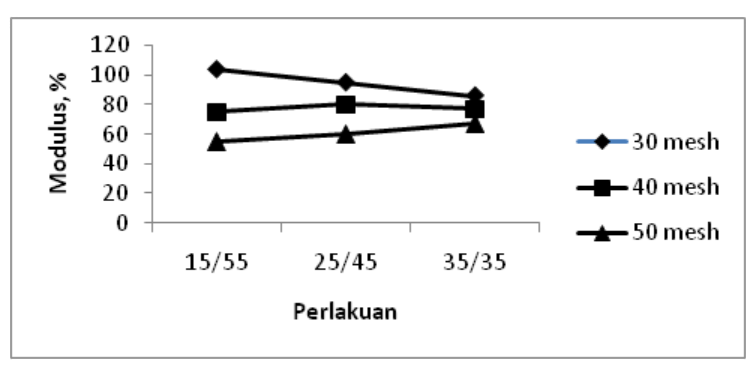

Gambar 4. Hasil uji tegangan tarik sebagai bahan pembuatan kompon karet dengan menggunakan tepung kulit kerang setelah pengusangan

Nilai tegangan tarik, semakin kecil ukuran partikel dan campuran tepung kulit kerang yang di gunakan nilai tegangan tarik cenderung menurun hal ini dikarenakan kompon karet yang dihasilkan memiliki porositas yang semakin besar (Rezeki dan Karolina, 2013). Kompon karet sebagian bahan penunjang yang digunakan dalam jumlah besar yaitu bahan pengisi, dalam penelitian ini bahan pengisi yang digunakan tepung kulit kerang. Tepung kulit kerang memiliki senyawa $\mathrm{SiO}_{2}$ yang rendah yaitu $\mathrm{SiO}_{2}$ 7,88\% (Maryam, 2006), sehingga silika memiliki interaksi yang lemah dengan polimer dan memiliki kecenderungan yang kuat untuk menggumpal (aglomerasi) serta membentuk jaringan-jaringan fillerpada kompon karet (Wang, 2001) sehingga, 
terdapat gumpalan-gumpalan di dalam kompon dan mempengaruhi kualitas kompon karet yang dihasilkan.

\section{SIMPULAN}

Hasil penelitian menunjukkan bahwa karakteristik fisik kompon uji visual untuk seluruh formula yaitu tidak cacat, hasil uji setelah pengusangan meliputi kekerasan (hardness) berkisar 56-64 shore A, tegangan putus (tensile strength)106-129 kg/cm ${ }^{2}$ dan perpanjangan putus (elongation at break) $336-579 \%$, sedangkan hasil uji fisik kompon tegangan tarik (modulus 55-104\%.

Hasil uji yang dihasilkan untuk semua parameter memenuhiSNI 06-7031-2004 persyaratan mutu karet pegangan setang (grip handle) sepeda motor.

\section{DAFTAR PUSTAKA}

Agustini, T.W. Fahmi A.S. Widowati I dan Sarwono, A. 2011. Pemanfaatan limbah cangkang kerang simping (Amusium pleuronectes) dalam pembuatan Cookies kaya kalsium. Jurnal pengolahan hasil perikanan Indonesia, volume XIV Nomor 1.

Badan Pusat Statistik. 2014. Dinas Perkebunan Provinsi Sumatera Selatan. Sumatera Selatan Dalam Angka.

Chandra, R dan Rustgi, R, 1997. Polymer Degradation and Stability, 56, 185.

Dharma, B. 1988. Siput dan Kerang Indonesia, Penerbit Erlangga.

Ellul, M.D dan D.R. Hazelton. 1994. Chemical surface treatments of Natural Rubber and EPDM Thermoplastic Elastomers: Effect on Friction and Adhession, Rubber Chem. Technol, R.T. vanderbilt Company Inc: Ohio.

Haris, U. 2004. KaretAlam Havea dan Industri Pengolahannya. Balai Penelitian dan Teknologi Karet. Bogor.

Hendrawan, M.A dan Purboputro P.I. 2015. Pengaruh komposisi bahan komposit karet terhadap kekuatan Tarik dan keausan bahan karet luar ban pada lintasan semen. Prosiding SNST ke-
6. Fakultas Teknik Universitas Wahid Hasyim Semarang.

Kumar, Ch SSR and NijasureM. A. 2007. Vulcanization of Rubber, Resonance April 1977 page 55-59.

Long, harry. 1085. Basic Compounding and Processing of Rubber, University of Akron: Ohio.

Maryam, S. 2006. Pengaruh Serbuk Cangkang Kerang Sebagai Filter Terhadap SifatSifat dari Mortar. Skripsi. FMIPA. USU

Nadjib, 2008. Studi pemanfaatan kulit kerang sebagai bahan penyusun pada pembuatan lem kaca. Berk. Penel. Hayati 13(153-156). ITS. Surabaya.

Surest, A.H, Aria Risma Wardani dan Resi Fransiska, 2012. Pemanfaatan Limbah Kulit Kerang untuk Menaikkan pH pada proses Pengelolaan air rawa menjadi air bersih. Jurnal Teknik Kimia UNSRI

Standar Nasional Indonesia. 2004. Persyaratan Mutu Karet Pegangan Setang (GripHandle) Sepeda Motor. SNI 06-7031-2004.

Thomas, 2005. Disain Kompon. Balai Penelitian Teknologi Karet Bogor.

Retno, E et al. 2012. Pembuatan Ethanol Fuel Grade Dengan Metode Adsorbsi Menggunakan Adsorben Granulated Natural Zeolite dan CaO. Spionsium Nasional RAPI XI FT UMS-2K012. Teknik Kimia. Fakultas Teknik. Universitas Sebelas Maret.

Rezeki, A.S dan Karolina R., 2013. Pengaruh substitusi abukulit kerang terhadap sifat mekanik beton. Jurnal Teknik Sipil USU, Vol 2, No 2. Medan.

Sahara, R. 2011. Komposisi Cangkang Kerang Darah. Institut Pertanian Bogor. Jawa barat.

Wang, M.J. 2001. Carbon-Silica Dual Phase Filler, A New Generation Reinforcing Agent For Rubber. Rubber Chemistry and Technology.

Kania F, Wijayanti M, SariTI, Fachry Rdan Rahmaniar, 2014.Pemanfaatan limbah tepung kulit kerang sebagai filler pengganti dalam pembuatan grip handle motor dari karet. Prosiding Teknik Kimia Universitas Sriwijaya. 
Yuniari, A., Any, S., dan Buchori, A. 2001. Optimalisasi Kondisi Proses Vulkanisasi terhadap Sifat Fisis Kompon Karet yang Menggunakan Bahan Pengisi Jenis Silikat. Prosiding Seminar Nasional Kimia. Surakarta.
Yuniati. 2010. Studi pemanfaatan kulit kerang (Andara Ferruginea) sebagai bahan pengidi produk latex karet alam dengan tekhnik pencelupan. Universitas Sumatera Utara. Medan. 